\title{
Facilitating English Learners' Speaking: Toastmasters Meeting as a Format for the ESL Speaking Class
}

\author{
Zhanna Shatrova \\ School of Foreign Languages, Muğla Sıtkı Koçman University \\ 206 School of Foreign Languages, Mugla 48000, Turkey \\ Tel: (90) 252-211-4961_E-mail: zhannashatrova@mu.edu.tr
}

Received: January 2, 2016 Accepted: January 14, 2016 Published: January 15, 2016

doi:10.5296/ijele.v4i1.8861 URL: http://dx.doi.org/10.5296/ijele.v4i1.8861

\begin{abstract}
Speaking skills come upfront in teaching English due to rapidly growing global demand for professionals with adequate level of the language proficiency. New approaches to teaching speaking are needed to meet these demands. The article describes how Toastmasters meeting format was utilized in a speaking course for the students at a Turkish university. The project had a twofold objective: to incorporate the format to the speaking course and investigate the effect of such a classroom environment on students' preparedness for speaking assessment and their speaking anxiety. The paper presents the rationale, timeline, and components of the class. Engagement of the participants in a meaningful project and speaking activities in a non-threatening atmosphere contributed to improving students' oral communication skills and decreasing speaking anxiety. Such format is believed to be beneficial for university level students in their academic progression.
\end{abstract}

Keywords: Speaking anxiety, Communicative competencies, Experiential learning, Toastmasters 


\section{Introduction}

Growing local, national, and global demands (Khamkahien, Attapol, 2010) for the professionals with advanced level of English shape the policies and curricular in English Language Teaching. About 60 countries have already introduced English as medium of instruction into their education systems, thus warranting more attention to ELT approaches (Dearden, 2014).

\subsection{Problem}

Speaking remains the most challenging skill for ESL students to attain. Even the graduates from English Language Teaching departments often experience a mismatch between their thoughts and ability to communicate them in English (Tum, 2015). The study by Dearden (2014) revealed that 20 percent of English teachers in public schools in Turkey had only CERF (Common European Framework of Reference) A2 language and they still experienced speaking anxiety which prevented them from being effective language teachers. There are a couple of reasons that explain this phenomenon. First, traditional class formats do not usually provide sufficient tools and motivation for the students to develop and improve their speaking skills. Next, teachers are usually viewed as speaking "anxiety provokers" (Ewald, 2007).

New approaches are needed for classroom instructors to create a non-threatening learning environment to motivate students to speak and use English to express their ideas. Such approaches ensure interactive nature of the classroom in the forms of role-plays and simulations (Farris \& Taggs, 1996). It can also be argued that these approaches could assist the students in their preparation for further academic studies and career advancement. A class in the format of a Toastmasters meeting (http://www.toastmasters.org) could meet all these requirements.

\subsection{Why Toastmasters}

My concerns were about the students' academic performance and the level of their speaking class anxiety; hence the belief that I should change my approach guided me in the decision to introduce a new form to my speaking class. Case study design best met my objectives. It was focused on the particulars of a program, individual, or place (Rossman \& Rallis, 1998), which, in this case, was the structure of the Toastmasters meetings to be utilized for the classroom environment. Toastmasters' format was assumed to enhance students' learning in the classroom by actively engaging them in a real-life activity or project which would facilitate development of interaction and presentation speaking skills and decrease speaking anxiety. Several considerations enforced this assumption. First, Toastmasters meetings include impromptu speeches and prepared speeches that reflected (correlate) the standardized assessment design for speaking at the School of Foreign Languages of Mugla Sitki Kocman University where I teach. I speculated that students practicing in these kinds of speaking activities on a weekly basis would become familiar with the challenges of each of the assessment forms, improve their speaking skills, and learn speaking anxiety management techniques. Second, this format would allow the students to get away from the traditional classroom setting which is often perceived by the students as boring, far from their real life 
environment. Moreover, it would maximize the time of each student speaking during the class period. Third, I had been a member of the Toastmasters' Club for eight years and I know firsthand about the benefits of such meetings for becoming a confident speaker.

The purpose of the study was to investigate the effectiveness of the Toastmasters' format of the classroom on students' speaking skills and reducing speaking anxiety. I identified the following research questions:

1. How does a Toastmasters' class motivate students to speak and decrease their speaking class anxiety?

2. How effective is the format for assisting the students to be well prepared for the speaking exam and project presentation?

\section{Literature Review}

Changing the focus in ESL curriculum to communicative techniques teaching speaking is gaining momentum (Hinkel, 2003; Richards, 2008). Researchers actively investigate anxiety related to speaking and factors impacting communicative competencies. Extensive body of literature looks at the approaches to teaching speaking skills, which "has long been the focus of methodological debate" (Richards, 2008, p.19). The discussion is focused on general issues and conceptual questions, while best practices do not seem to get due attention.

\subsection{Speaking Anxiety}

Language learners' anxiety received considerable attention in the literature. Researchers differentiate between trait, state, and state specific anxiety (Woodrow, 2006). For the language classroom it is state specific anxiety that impedes the students' ability to be effective speakers. Ewald (2007) used an analogy with the amusement park: even if you like the rides you still feel the anxiety. Language learners go through a similar feeling. They experience anxiety when they have to interact with each other, provide information or share their opinion, and do some sort of presentation. Richards' (2008) provided the classification of talks: talk as interaction, transaction, and presentation. The students tend to get anxious in all types of talks. In the discussion of ways to assist the students to cope with their fear, Richards pointed out that the instructor should, first, determine what type of talk the class is going to focus and then identify the goals of the class and plan the activities accordingly. Instructional context plays a critical role in the level of anxiety (Sung-Yeon, 2009). Academic tasks especially formal presentations reinforce speaking anxiety of students (Ferris \& Taggs, 1996). Grace and Gilsdorf, (2004) discussed their accounting students' apprehensiveness to speak in English.

The fear of making language mistakes is not the only cause of students' anxiety. Dissatisfaction with classroom instruction and boring course materials, unsuitable methodology, and irrelevant topics are linguistic factors (Cheng, 2000; Ewald, 2015). Effiong (2015) also pointed out non- linguistic factors impacting FLA, such as "dress code, teacher age, friendliness, lack of rapport between the teacher and the students, lack of motivation, and 
even students' mood on a particular day" (p. 442). Jackson (2002) added fear of losing face and the passive habits the learners acquired during previous school experiences. Positive reinforcement of students' performance and "discouragement of a perfectionist attitude" (Ewald, 2007, p.134), general friendly classroom environment, humor and teacher-student collaboration assist in decreasing FLA (Effiong, 2015).

\subsection{Approaches to Teaching English Speaking}

In the discourse about methods of teaching English speaking, educators agree on several issues. With changing approaches and shifting the foci in ELT toward communicative competencies the content of the majority of the textbook remains the same (Swaffar, 2006). It does not sufficiently consider learners' communicative competences, their cultural background, interests and beliefs. The emphases should be on developing fluency in oral communication encouraging students to speak in the range of performance conditions and topics (Dolati \& Mousavi, 2014; Richards, 2008) and pushing them "to produce spoken language in unfamiliar areas" (Nation \&Newton, 2009, p.115).

To encourage students to express themselves in various situations and environments the instructors should utilize the eclectic approach (Swaffar, 2006). Integrated and dynamic multi-skilled instructional models with a focus on meaningful communication need to become a core of the ESL teaching curriculum (Hinkel, 2006, p.113). Discussing traditional communicative techniques and methods such as role plays, project and group work, the literature underlines the importance of practicing the attained skills in outside-the-classroom situations and moving to communicative tasks which are unfamiliar to students (Al-Darwish \&Taqil, 2015; Ferris \& Tagg, 1996; Sung-Yeon, 2009). Creative and natural ways to review grammatical topics (Ewald, 2007); presentations as a way to practice public speaking (Salwa \& Hanan, 2015); "communicating-to-learn" techniques such as timed self-introduction, presentation, response to the instructor's question, and summary of the current news feature (Grace \& Gilsdorf, 2004) are called to boost the willingness to speak and develop communicative competencies.

\subsection{Toastmasters as an Approach}

Two sources in literature (Grace \& Gilsdorf, 2004; Watkins \& Green, 2003) mentioned Toastmasters International (http://www.toastmasters.org.) as a tool to facilitate students' speaking skills. However, it was viewed not as a classroom approach, but as an extracurricular activity. The instructors advised the students to attend the meetings of the local Toastmasters' chapters and practice their skills there. Usually, the students visited those meetings as guests and observers or became members of the club. The literature did not present any evidence of Toastmasters' format being utilized in the ESL classroom.

\section{Study Design}

\subsection{Theoretical Frame: Experiential Learning Theory}

Kolb's (1984) Experiential Learning model informed and shaped my research, for this model 
builds on the principle that language learning in the ESL classroom is "facilitated when students are cooperatively involved in working on a project or task, and when the project includes the phases of exposure, participation, internalization, and dissemination" (Knutson, 2003, p.56).

The Toastmasters club format for the speaking class was viewed as the project which would allow the students to experience their learning and benefit from it short and long term. As such, the format met the requirements for the experiential learning model. It was communicative, real life, and meaningful. The planning and designing of the class considered four phases. The frequency of the classes and the duration (academic year) ensured sufficient time to go through all phases and increase the level of difficulty for speaking tasks (Dashti, Akbar \& Taqi, 2014). The project was assumed not only to grant the students ownership of the learning process but also develop their "cognitive and employability skills (critical reflection, self-evaluation, and leadership) (Knutson, 2003, p.60).

Exposure phase started with orientation when the students were initiated to the project. During the orientation class the students got familiar with the history of Toastmasters, the structure of the meetings, goals and benefits. I also shared my personal experience and presented the rational for my decision to start the project. Exposure phase was manifested in regular weekly meetings and adjustments to the format when it was necessary. The structure of the class ensured active participation of each student, as all the students were required to do impromptu speeches, deliver a 7 minute speech and take each role at least once during the semester. The focus in the class was on linguistic interaction. Reflection on learning through debriefing and feedback from the students with evaluative roles at each meeting promoted internationalization of acquired skills and experiences. The speaking exam and project presentation were the near future venues to disseminate learning. At the same time, the students were expected to get real-life competencies to reach social, academic, and career related goals; thus creating a clear link between the classroom and outside world.

\subsection{Site and Participants}

The participant sample was comprised of 45 students from three pre-intermediate groups of the preparatory school at a Turkish University. These students had 20 hours of English classes per week; six hours were assigned as speaking classes. The objective of speaking classes was to promote and facilitate students' ESL speaking and communication skills. Forms of speaking performance assessment included project presentation and a speaking exam.

Out of 45 students eight had some speaking experience before admission to the University. This experience included sporadic short encounters with foreigners and very limited speaking time in the classroom in high school. The other 37 student admitted that they had not had any opportunity to practice English speaking; therefore, the challenges in teaching speaking in this particular educational environment included but were not limited to:

-- Zero or very little experience in ESL speaking in high school which caused students' apprehension of speaking English in class.

-- Viewing the instructor as a figure of authority "preaching to the crowd" and the students 
following the teacher's agenda with them taking no initiative or engaging in meaningful discussions. This attitude stemmed from the system in public schools (Kizildag, 2009).

-- Fear of speaking.

--Anxiety about presenting in front of public.

\subsection{The Study Time-line}

\subsubsection{Questionnaire on Speaking Anxiety}

Public Speaking Class Anxiety Scale (PSCAS) (Kriangkrai Yaikhong \& Siriluck Usaha, 2012). The questionnaire was administered in the second week of classes, and the week before the speaking exam.

\subsubsection{Orientation Meeting (second week of the fall semester)}

The rationale for having a class in the Toastmasters format was firstly presented to the program coordinators. With administration support and approval, I proceeded with an orientation meeting in each of the three groups introducing the plan to change the format of a two hour class to a weekly meeting for practicing public speaking.

The key questions for the orientation meeting were: WHAT (what are we going to do?) WHY (Why is it going to be Toastmasters) and HOW (How are we going to do it?). First, I provided the information about the Toastmasters International pointing out the similarities of the types of speeches and forms of assessment of students speaking skills (project presentation and speaking exam). I also shared my experience of being a Toastmaster and my beliefs about both short-term and long-term benefits for the students. Then, I presented the outline of the class: table topics and prepared speeches each followed by evaluations. I emphasized that all students were supposed to do a table topic: it was crucial for each student to be exposed to this activity on a regular basis; they had an opportunity to practice their speaking skills in the same environment they would have during the speaking exam later. The votes for the Best Table Topic promoted critical thinking of the students, for not only they casted their votes but also they were supposed to give their feedback and explain their choice. In the prepared speaking portion of the meeting, several toastmasters would give a prepared presentation or speech before the group. The next topic to consider was the mission of the club. I suggested brainstorming of the changes for the mission from the script. The final text was approved at the end of the second hour of the class.

Finally, I did some simulations to assist the students with the models of how each part of the class would look like. Orientation class let the students have a better idea about their roles and responsibilities for this particular class every week.

\subsubsection{Weekly 2- hour Classes/Meetings (23 weeks of fall and spring semester)}

The typical meeting format and the description of the roles and parts of the meeting are presented in Table I. 
Table I. Meeting agenda

\begin{tabular}{|c|c|}
\hline Event/Time & Description \\
\hline Presiding officer (2-3 min) & $\begin{array}{l}\text { Opens the meetings, announces the mission, } \\
\text { introduces the students with the roles, asks } \\
\text { about new and old business. }\end{array}$ \\
\hline Table Topic Master & $\begin{array}{l}\text { Moderates the Table Topic session (calls on } \\
\text { the students and offers topics for impromptu } \\
\text { speeches). }\end{array}$ \\
\hline Impromptu speeches (30 min) & $\begin{array}{l}\text { Students stand up and speak on the topics } \\
\text { offered by Table Topic Master. }\end{array}$ \\
\hline Reports (10 min) & $\begin{array}{l}\text { Grammarian, Eh-Ah counter, Timer, } \\
\text { Pronunciation Checker present their reports. }\end{array}$ \\
\hline Votes for Table Topic of the Week ( $5 \mathrm{~min})$ & $\begin{array}{l}\text { Table Topic Master hands out the voting slips } \\
\text { and the students cast their votes for the } \\
\text { student whose speech they liked most of all. } \\
\text { After counting the votes Table Topic Master } \\
\text { presents the award to the winner. }\end{array}$ \\
\hline Participants' feedback (5 min) & $\begin{array}{l}\text { General Evaluator (instructor) asks several } \\
\text { students for feedback. The students explain } \\
\text { their choice of the winner. }\end{array}$ \\
\hline \multicolumn{2}{|l|}{ Break (10 min) } \\
\hline Presiding officer (2min) & $\begin{array}{l}\text { Announces the second part of the meeting } \\
\text { and present the speakers who are going to } \\
\text { deliver prepared speeches. After the } \\
\text { introduction gives the floor to the speakers. }\end{array}$ \\
\hline 2 prepared speeches $(20 \mathrm{~min})$ & The students present their prepared speeches \\
\hline Participants' feedback (15 min) & $\begin{array}{l}\text { General Evaluator asks for the feedback from } \\
\text { the students about the prepared speeches. The } \\
\text { students are encouraged to be specific about } \\
\text { strengths and weaknesses of the speeches. } \\
\text { They are supposed to evaluate the structure } \\
\text { of the speech, general flow, fluency, } \\
\text { pronunciation, speaker's body language, eye } \\
\text { contact, voice pitch, etc. }\end{array}$ \\
\hline General evaluation (10 $\mathrm{min})$ & $\begin{array}{l}\text { The instructor comments on the meeting, } \\
\text { gives the feedback on the performance of the } \\
\text { students with roles, provides tips for } \\
\text { improving speaking skills. }\end{array}$ \\
\hline Presiding officer (5 min) & $\begin{array}{l}\text { Asks for volunteers for roles for the next } \\
\text { meeting, gives some closing remarks and } \\
\text { adjourns the class. }\end{array}$ \\
\hline
\end{tabular}




\section{I Macrothink

\section{Data Collection and Analysis}

Data collection included a questionnaire on classroom speaking anxiety, teacher's observation of each meeting and reflection, and focus groups.

\subsection{Questionnaire}

To identify the level of classroom speaking anxiety the students were offered the questionnaire based on Public Speaking Class Anxiety Scale (PSCAS) (Kriangkrai Yaikhong \& Siriluck Usaha, 2012). This questionnaire consisted of seventeen items which were answered on a five-point Likert scale. All items were analyzed on four factors which comprised the construct of English speaking class anxiety. Factor 1 (communication anxiety) was demonstrative of fear of criticism for speaking, nervousness about being called or waiting for the turn to speak, and bodily response towards speaking English. Factor 2 (comfort in speaking English) was related to learners' level of comfort in any kind of speaking activities. Factor 3 (speaking test anxiety) was indicative of fear of inadequate and low performance at the speaking exam. Factor 4 (anticipated anxious behaviors in speaking English) was reflective of possible reaction and behaviors caused by anxiety. The scores were categorized as high, medium, and low anxiety (Kriangkrai Yaikhong \& Siriluck Usaha, 2012, p. 32). The questionnaire was offered to the students two times: the second week of the fall semester and the week before the speaking exam at the end of the spring semester. The results of the questionnaire are presented in the diagram.

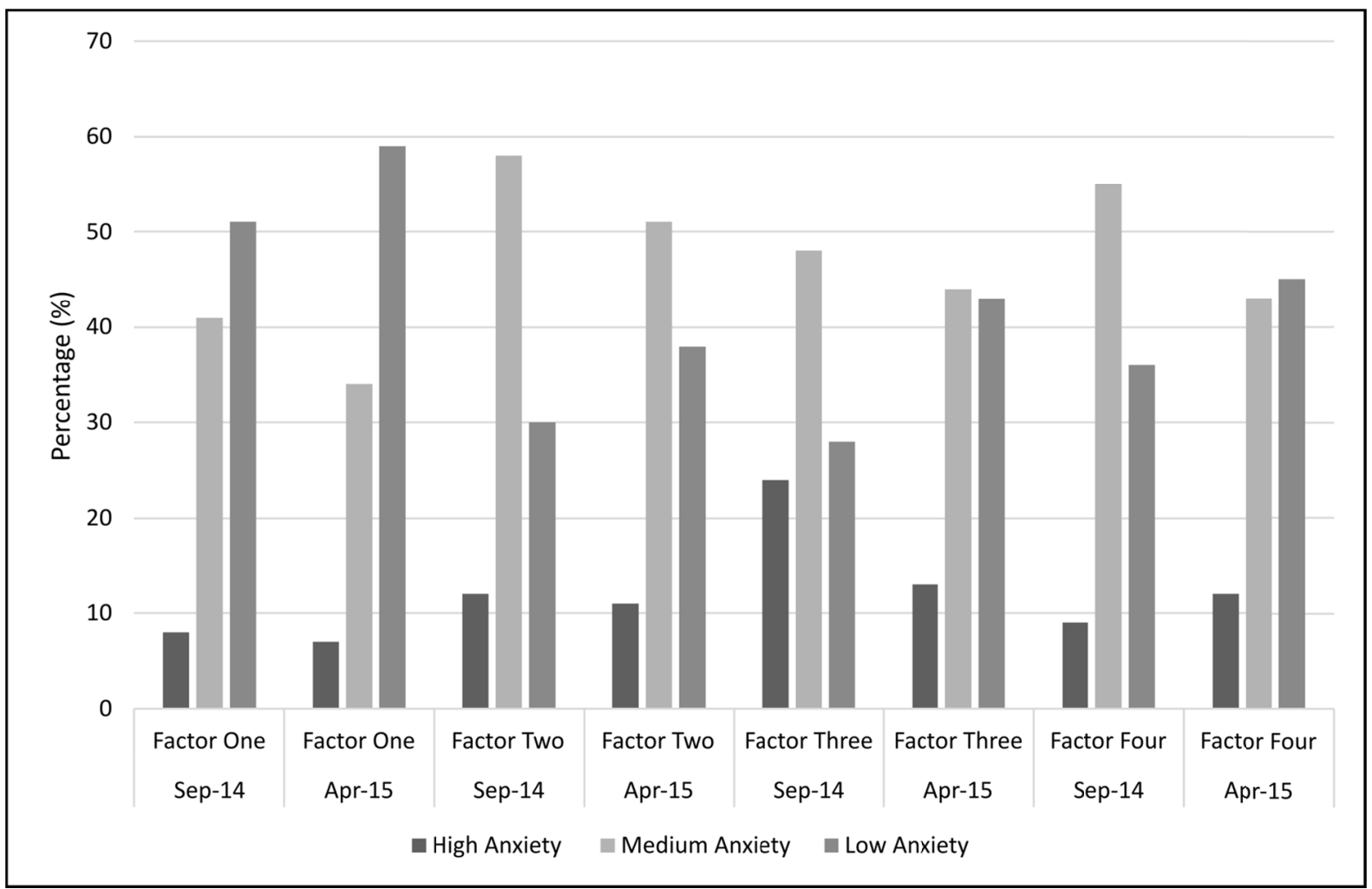




\section{Macrothink}

They showed consistent positive dynamics in shifting anxiety from high to low across all four factors. The most significant decrease from 28 to 43 percent was reported in speaking test anxiety factor (Factor 3). The students' performance at the exam and presentation supported the data from the survey. The average grades for project presentation ranged from $80 \%$ to $92 \%$ depending on the group. Speaking exams results were also higher than in the other groups: the average score was 80 .

\subsection{Analytical Memos}

After each meeting I wrote analytical memos in which I reflected on the dynamics of the meetings, ups and downs, the AHA and WOW moments, and analyzed the progress of the groups. The excerpt from analytical memos (Week 6) is as follows:

\begin{tabular}{|c|c|}
\hline $\begin{array}{l}\text { Wow moments: } \\
\text {-- Group } 101 \text { meeting ( Aziz as presiding } \\
\text { officer, table topics) }\end{array}$ & $\begin{array}{l}\text { Aziz was very good as a presiding officer: self-confident, } \\
\text { efficient in terms of spoken language and body language, } \\
\text { and successful as a leader. He obviously was enjoying } \\
\text { the whole process, his face relaxed with a light smile, } \\
\text { hands on the desk without shaking. } \\
\text { In my notes on the table topic session I put only wow, } \\
\text { great, or very good final remarks. The students made a } \\
\text { big step forward in getting rid of speaking anxiety: they } \\
\text { were actually listening to their classmates looking at } \\
\text { them instead of sitting stiff and dreading their turn. } \\
\text { Abdurahman was voted as the best table topic second } \\
\text { time (this is a promising accomplishment) } \\
\text { What is great in the teaching profession is that there are } \\
\text { no dull moments. As a professional, you always have to } \\
\text { be ready for unexpected and unpredictable moments. } \\
\text { Group } 101 \text { was a discovery, they were shining this week. } \\
\text { Group } 102 \text { which usually is better and more creative } \\
\text { during the meetings was surprisingly down this week } \\
\text { (more about it in the challenge section). Group } 103 \\
\text { keeps being inconsistent - it is always hard to predict the } \\
\text { dynamics in this group. } \\
\text {--I have to admit that I did not handle the challenges of } \\
\text { the meeting in Group102 too well. Tural as a Topic } \\
\text { Master chose to expand his role and turned the session } \\
\text { into discussion or conversation. With an intention to help } \\
\text { the students he was asking them questions after they } \\
\text { started speaking and was leading them in their thoughts. } \\
\text { waiting for their turn. I had to interfere and remind him }\end{array}$ \\
\hline
\end{tabular}




\section{Ml Macrothink Institute}

\section{Challenges:}

--Tural (102), Group 102 meeting (general dynamics, Gulben, Esra's speech about seven wonders)

-Finding the awards for the best topic.

Discoveries: Tugba and Fevzimert (102), Ismet (103), Sechil (101) that he could not interrupt the person after he gave the person the topic to speak. Despite my reminder, Tural kept doing it. I did not tell him anything more, but my body language and facial expression were very telling. The students saw it which was not good. Meanwhile Tural was so engaged in leading table topics that he did not pay attention to my reaction. As the result of these disruptions, the students were stiff and reserved in their speeches.

Gulben who was supposed to prepare one of the speeches did not show up. I think I'll have to deal with irresponsibility of students with roles from time to time for quite a while. The second speech was delivered by Esra. It was about Seven World Wonders. I always wondered why this particular topic is so popular with the students for project presentation yet the presentations are usually the most boring. They are full of numbers and facts and sound like a laundry list of dry facts. Esra got in the same trap. In my feedback, I pointed out the major drawbacks of such an approach and advised the students to think twice before choosing such topics for project presentation. We discussed the strategies how to narrow the focus of the speech.

The search for an award for the best table topic turned into quite an adventure. I visited several stores and could not find anything appropriate for the occasion. Finally, in the stationary store I saw the "smiley" man with graduation cap on the head and a book in one of the hands. Well, not exactly what I had in my mind, but at least it has an academic theme.

It is great to see more students come out and show sides of themselves which I was not aware of. These four students showed their potential this week: now I know that I can raise the bar for them to boost their progress. Tugba was more descriptive providing more details which is always a challenge for her. Sechil was not nervous and felt relaxed while speaking and this is progress. Ismet and Fevzimert surprised me with the deep meaning and philosophical approach to their 


\begin{tabular}{|l|l|}
\hline & $\begin{array}{l}\text { speaking. Fevzimert not only provided a very good } \\
\text { description of Aya Sofia but also spoke about the } \\
\text { significances of this historic site for Turkey. Ismet was } \\
\text { good in his reasoning about the meaning of life. } \\
\text { Usually Ismet is not active in class and may just goof } \\
\text { around. This change makes me think that he starts } \\
\text { finding motivation. }\end{array}$ \\
$\begin{array}{l}\text { Oops moments: } \\
\text {--vote slips for best table topic, all three }\end{array}$ & $\begin{array}{l}\text { I should remember to double check how the students } \\
\text { understand my instructions. Obviously, I was not clear } \\
\text { enough about the slips for best table topic vote. None of } \\
\text { the table topic masters did what I asked for (they wrote } \\
\text { questions on the slips, or thought the students would tell } \\
\text { the names). It is the lesson to learn. }\end{array}$ \\
Tip(s) of the week: & $\begin{array}{l}\text { I had time to practice functional phrases with the } \\
\text { students using prepared speeches. Some of the students } \\
\text { got the idea instantly, for some it was challenging. All of } \\
\text { them, however, liked counting the words. }\end{array}$ \\
-- Functional Phrase & --Students' approach to this type of class. \\
ance of progress: & $\begin{array}{l}\text { At this point, all the students meet the time requirement } \\
\text { for speaking. They seem to be relaxed during their table } \\
\text { Master. I do not have to remind about the day of the } \\
\text { meeting, and logistics of the meeting. It looks like they } \\
\text { completely accepted this idea and for them it is already } \\
\text { an established routine. }\end{array}$ \\
\hline
\end{tabular}

Analytical notes helped me monitor the dynamics of the meetings, see what worked well and what things did not meet expectations and need reconsideration. The memos also enabled me to keep track with each individual student's progress and provided information about the needs of particular students and the ways to meet those needs.

Viewing the meeting as an ordinary class was a major challenge at the beginning of the project. It took some time, at least three or four weeks, for the students to get used to the idea that it was a different activity and their instructor was a participant, not a figure of authority. It was especially hard for the students in the role of Presiding Officer as they had to take the leading role and moderate the meeting instead of looking all the time at the instructor asking for confirmation whether they were doing right things. The other students would also look only at the instructor during their speeches or feedback.

Predisposition to have fear of speaking, difficulty of finding ideas to support the argument, 
lack of critical thinking skills were the roots of challenges with impromptu speeches: the students did not believe that they could say quite a lot no matter how hard the topic might seem for them. As a result, some students would give up and say nothing or just couple sentences.

The feedback about the classmates' table topics and speeches was very general with lack of details. The students ended up retelling the speeches; they tended to focus more on their likes and dislikes of the content rather than the method of delivery or clarity of argument. Furthermore, the challenge was to be positive in their feedback and provide constructive criticism.

My modeling constructive feedback was instrumental in improving the students' speaking and critical thinking skills. I put the major focus on creating supportive environment and capitalizing on positives in the speeches and offering the ways how to improve rather than just criticize. Speaking tips assisted the students in their preparation for the prepared speeches. I made sure not only to introduce one tip every meeting but also to allocate some time to practicing those tips on the examples of the speeches presented by the students and using the table topics. The typical grammar mistakes and misuse of vocabulary were worked on in other classes.

The table topics the students chose showed evidence of the shift of the student's focus from very basic topics to the themes which demanded critical thinking or thinking out of the box. Such moves also required higher level of language proficiency. It was rewarding for me to see that the students utilized the things they learnt and practiced in their other English classes. Besides, I also benefited from it because I was doing impromptu speeches too. It facilitated motivation of the students: they felt more at ease because the instructor was not perceived as a teacher but as an ordinary participant of the meeting.

It should be noted that students were actively using online resources for the ideas for topics; however, some students preferred to come up with their own topics. At the beginning the topics were straightforward: Tell about the most memorable moment from your childhood? What music do you listen to when you are down? What is your favorite smart phone app? What nicknames did you have in your childhood? Why do people cry over the movies? What would you do for your best friend's BD? What do you admire almost about you parents? As the classes progressed Table Topic Masters opted to choose more challenging and thoughtprovoking questions: Can there be peace without war, happiness without sorrow, pleasure without pain? What would you say if the whole world were listening to you? Where do you find inspiration? What do you think about cloning? How would you describe freedom? How do you deal with somebody in a position of power who wants you to fail? What does Game of Thrones teach you about politics?

Table Topic of the Week award became an incentive for the students to do their best in delivering their topics. Out of 45 students in three groups 25 were nominated Table Topic of the Week at least once: some students got this award two and more times. One student was recognized five times. 
The student showed faster progress with table topics than with prepared speeches. They tended to be resistant and not motivated about the need to prepare their presentations. Quite often they chose the topics which they were not very passionate about. Furthermore, they had difficulty narrowing their topics and thus kept them quite broad: Pakistan, Christmas Traditions, Environmental Problems, Famous Sportsmen, for instance. The challenges the majority of the students experienced included: giving a good title to the speech, developing a strong thesis statement and topic sentences, concluding the speech with a strong paragraph. Additionally, the students had difficulty with nonverbal aspects of presentation such as body language, eye contact, voice volume and pitch, eye contact, etc.

I tried to allocate sufficient time during the second hour of the meeting to give feedback on the presented speeches and provide the students with the tips how to improve presentation skills. Craig Valentine's 52 Speaking Tips (http://www.52speakingtips.com/) served as a great resource of useful information about how to become a successful speaker. Taking into account the level of language proficiency of the students and the dynamics of the group I had to adapt some tips and materials to make them more understandable and relevant to particular audience. For instance, discussing Tip 45: Match and Move (how to make a connection with audience), we focused on the environment during the meetings and future project presentation at the end of the academic year. The tip, "Watch how they" are with someone who speaks before you." was put in the context of project presentation. We discussed with the students what they could do and how they could test the audience depending on the time of their presentation. Another tip, "Just feel your audience. Be there for a while with them." needed practice with the students. I decided to ask the students-presenters during the break of the meetings about the mood of the audience on that particular day and about their strategy how to begin their speech. Those brief conversations seemed to be very helpful for the students to get more prepared for the presentation. I also tried to find time for discussion and practicing nonverbal, extra-linguistic means of oral presentations such as eye contact, facial expression, para language, body movements, managing the space, etc.

\subsection{Focus Groups}

I formed three focus groups whom I interviewed before the speaking exam. At that point the students already had their project presentations and answered the questionnaire for the second time. Each group consisted of five students. The first group had the students who were the most successful in the role of Presiding Officer, the second group were the students who had most of the Table Topic of the Week wins, and the third group comprised of the students who were never nominated for the best table topic. The students were asked four questions: How helpful was the class for your study and life outside the classroom? What part of the class did you like most of all? What did you dislike about the class? What would you suggest to make it better? The first two groups capitalized on the benefits of the class: they found the class entertaining, gained more confidence while speaking, enjoyed presiding at the meeting and learned to think out of the box. "It felt good when I could speak without any fear and I could see that my classmates were listening to me attentively." "I was always looking forward to the meetings because it was different and not boring." "I liked to be in different roles especially presiding officer, it was cool to run the meeting and be in charge of everything going on in 
the class." "I felt very proud each time I was chosen a table topic of the week. I felt like a celebrity." The most interesting part for me was impromptu speeches because I could know my classmates more." "Doing the duties during the meetings". The third group though not enthusiastic did recognize the fact that the class helped feel less fearful about speaking, "at least I am not shaking anymore when I have to speak", " I did not like to be called upon to speak but I am not as much afraid of speaking exam now". For these students the most challenging part of the class were impromptu speeches while they liked to listen to their classmates' prepared speeches. It is important to mention that all three groups shared similar opinions about prepared speeches. The students were interested in listening to their classmates; however, they did not look forward to delivering the speech because of required time, effort, and research during the week.

The issue the groups brought up was the fact that the students eventually started feeling bored of everyone giving table topics. They suggested that maximum 7-8 students would give impromptu speeches, and the time saved could be used for more practicing the tips and brainstorming ideas for topics. Another suggestion included speech battles between two or three speakers with a certain type of speech (inspirational, humorous, etc.)

The data from the focus group discussion provided the insight of the students' perceptions of the class, understanding of their learning gains and frustrations, and ideas of how the class could be improved.

\section{Conclusion}

The findings of this study show evidence that Toastmasters' format can be utilized as an effective alternative to teaching speaking at the university level. It created a non-threatening environment in the classroom where students felt more comfortable and eager to speak without the fear of making mistakes hence decreasing their anxiety. The class in this format allowed the students to learn in an environment which was different from the one that were used to. During the meetings the students were completely immersed in the English language, they were the agents of the entire activity, taking ownership of learning. The format required active participation of every student even if some students did not feel like contributing at the beginning. Participation included table topics, feedback on the other students' performance, and self-evaluation. Doing the duties for the meetings, providing the feedback on classmates speaking facilitated their reflection on the progress in learning. This class raised motivation of the students to overcome their fear of speaking. The incentives like Best Topic of the Week award were additional sources of encouragement. Positive informal atmosphere of the meetings, interesting table topics, and the opportunity to express themselves in different roles during the year stimulated leadership which enforced their confidence in communication and speaking.

This class was instrumental in preparing the students for project presentations and speaking exams: they attributed their successful performance to the experience they gained at the meetings. More importantly, public speaking skills they obtained and developed would be 
very beneficial for them in further studies at the University and later on in their professional life. From personal communication with former participants I get confirmation that they do not experience difficulty with presentations of different types and class discussions at their departments.

It seems safe to assume that this type of the speaking class might be very effective for University level students to improve their speaking skills and assist in decreasing speaking anxiety.

\section{References}

Başıbek, N., Dolmacı M., Cengiz, B.C., Bür B., Dilek Y., \& Kara, B. (2014). Lecturers' perceptions of English medium instruction at engineering departments of higher education: A study on partial English medium instruction at some state Universities in Turkey. Procedia Social and Behavioral Sciences, 116, 1819-1825. http://dx.doi.org/10.1016/j.sbspro.2014.01.477

Cheng, X. (2000). Asian students' reticence revisited. System, 28, 435-446. http://dx.doi.org/10.1016/S0346-251X(00)00015-4

Craig Valentine. 52 Speaking Tips. Retrieved from http:/www.52speakingtips.com/

Dashti, Abdulmohsen A., Akbar, Rahimah S., \& Taqi, Hanan A. (2014). Inıestigating English major students' attitudes towards the efficiency of the "Conversation" course. International Journal of English Language Teaching, 2(4), 56-66.

Dearden, J. (2014). English as a medium of instruction - a growing global phenomenon: phase 1 [Interim report. British Council / University of Oxford]. Retrieved from http://www.britishcouncil.org/sites/britishcouncil.uk2/files/english_as_a_medium_of_instruct ion.pdf

Doğançay-Aktuna, S., \& Kiziltepe, Z. (2005). English in Turkey. World Englishes, 24(2), 253-265. http://dx.doi.org/10.1111/j.1467-971X.2005.00408.x

Dolati, R. I., \& Mousavi, S. N. (2014). Non-native speaking learners (N.N.S.L.) strategies (metacognitive, cognitive, and affective strategies). International Journal of English Language Teaching, 2(2), 37-60.

Effiong, O. (2015). Getting them speaking: Classroom social factors and foreign language anxiety. TESOL Journal, 1-30. http://dx.doi.org/10.1002/tesj.194

Ewald, J.D. (2007). Foreign language learning in upper-level classes: Involving students as researchers. Foreign Language Annals, 40(1), 122-142. http://dx.doi.org/10.1111/j.1944-9720.2007.tb02857.x

Ferris, D., \& Tagg, T. (1996). Academic listening/speaking tasks for ESL students: Problems, suggestions, and implications. TESOL Quarterly, 3:0(2), 297-317. http://dx.doi.org/10.2307/3588145 


\section{MInstitute Macrothink $_{\text {Int }}$}

International Journal of English Language Education

ISSN 2325-0887

Grace,D. M., \& Gilsdorf, W. J. (2004). Classroom strategies for improving students' oral communication skills. Journal of Accounting Education, 22, 165-172. http://dx.doi.org/10.1016/j.jaccedu.2004.06.001

Hinkel, E. (2006). Current perspectives on teaching the four skills. TESOL Quarterly, 40(1), 109-131. http://dx.doi.org/10.2307/40264513

Jackson, J. (2002). Reticence in second language case discussions: Anxiety and aspirations. System 30, 65-84. http://dx.doi.org/10.1016/S0346-251X(01)00051-3

Khamkahien, Attapol (2010). Teaching English speaking and English Speaking tests in the Thai Context: A reflection from Thai Perspective. English Language Teaching, 3(1), 184-190.

Kim Sung-Yeon (2009). Questioning the stability of foreign language classroom anxiety and motivation across different classroom contexts. Foreign Language Annals, 42(1), 138-157. http://dx.doi.org/10.1111/j.1944-9720.2009.01012.x

Kizildag, A. (2009). Teaching English in Turkey: Dialogues with teachers about the challenges I public primary schools. International Electronic Journal of Elementary Education, 1(3), 188-201.

Knutson, S. (2003). Experiential learning in a second-language classroom. TESL Canada Journal, 20 (2), 52-64.

Kolb, D. (1984). Experiential learning: Experience as the source of learning and development. Englewood Cliffs, NJ: Prentice-Hall.

Kriangkrai Yaikhong \& Siriluck Usaha (2012). A measure of EFL public speaking class anxiety: Scale, development and preliminary validation and reliability. English Language Teaching, 5(12), 23-35. http://dx.doi.org/10.5539/elt.v5n12p23

Nation, I. S. P., \& Newton, J. (2009). Teaching ESL/EFL listening and speaking. New York and London: Routledge. New York: Cambridge University Press.

Richards, J. C. (2013). Curriculum approaches in language teaching: forward, central, and backward design. RELC Journal, 44(1), 5-33. http://dx.doi.org/10.1177/0033688212473293

Richards. J. C. (2008). Teaching Listening and Speaking: From Theory to Practice. New York: Cambridge University Press.

Safaa M. Abdel halim Aly (2014). Enhancing English prospective presentational communication skills and intercultural competence: Post-process based program. International Journal of English Language Teaching 2(3), 15-36.

Salwa H. Al-Darwish, \& Hanan A. Taqi. (2015). EFL presentations-investigating the effect of confidence and experience. International Journal of English Language Teaching, 3(1), 74-88.

Swaffar, J. (2006). Terminology and its discontents: Some caveats about communicative competencies. The Modern Language Journal, 90, 246-249. http://dx.doi.org/10.1111/j.1540-4781.2006.00395_2.x 


\section{Macrothink}

International Journal of English Language Education

ISSN 2325-0887

2016, Vol. 4, No. 1

Thompson, A.S., \& Khwaja, A.J. (2015). Foreign language anxiety in Turkey: the role of multilinguism. Journal of Multilingual and Multicultural Development, 1-18. http://dx.doi.org/10.1080/01434632.2015.1031136

Toastmasters International. Retrieved from http://www.toastmasters.org

Tüm, D. O. (2015). Foreign language anxiety's forgotten study: The case of the anxious preservice teacher. TESOL Quarterly, 49(4), 627-658. http://dx.doi.org/10.1002/tesq.190

Watkins, S.E., \& Green, R. (2003). Speaking and writing proficiency of international graduate students in elective, mentoring environments. Journal of Engineering Education, 92(2), 147-154. http://dx.doi.org/10.1002/j.2168-9830.2003.tb00753.x

Woodrow, L. (2006). Anxiety and Speaking English as a Second Language. RELC (Regional Language Center) Journal, 37, 308-326. http://dx.doi.org/10.1177/0033688206071315

\section{Copyright Disclaimer}

Copyright for this article is retained by the author(s), with first publication rights granted to the journal.

This is an open-access article distributed under the terms and conditions of the Creative Commons Attribution license (http://creativecommons.org/licenses/by/3.0/). 